\title{
ORAL FINDINGS AND TREATMENT OF A PATIENT WITH CYCLIC NEUTROPENIA
}

\author{
Eun-Joo Kang, Nam-Ki Choi, Seon-Mi Kim \\ Department of Pediatric Dentistry, School of Dentistry, Chonnam National University
}

Cyclic neutropenia is a hematologic disorder characterized by a marked decrease in the number of circulating neutrophils occurring at regular intervals and after this period, the level of neutrophils usually recovers to a normal range. The clinical symptoms of cyclic neutropenia include fever, malaise, headaches and oral findings associated with painful soft tissue ulceration where lips, tongue and gingiva are typically involved.

A 4 year 1 month old boy was presented to the hospital. His chief complaint was mobility of his teeth and swollen gums. The patient had suffered from cyclic neutropenia. Clinical examination revealed evident decay on all primary teeth except for the mandibular anterior teeth and localized alveolar bone loss around mandibullar right and left first primary molars which have mobility was notable. The patient was diagnosed with multiple dental caries, gingivitis and localized periodontitis associated with cyclic neutropenia and treated based on it.

The dental treatment, including regular tooth care and appropriate treatment of dental caries or gingivitis, is essential for patients suffering cyclic neutropenia. Especially, proper care at an early stage is needed for young patients to minimize the unwanted consequences for permanent teeth development.

Key words : Cyclic neutropenia, Gingivitis, Alveolar bone loss, Oral management

\section{I. 서 론}

주기성 호중구 감소증(cyclic neutropenia)은 약 21일 (14 36일)을 주기로 하여 호중구의 수가 감소하고 이 기간이 5 10 일 지속되며 이 기간 이후에 호중구의 수가 다시 정상으 로 회복되는 특징을 보이는 혈액질환이다 ${ }^{122}$. 이 질환은 1910 년, 주기적으로 호중구의 수가 감소하고 열이 발생하며 구강 내 궤양을 보이는 19 개월의 남자아이에게서 최초로 보고되었다 ${ }^{3}$.

약 $30 \%$ 의 환자에서는 상염색체 우성으로 유전되며 나머지 경우의 원인은 정확히 밝혀져 있지 않다 ${ }^{1}$. 호중구의 수가 감소 하게 되는 메커니즘에 대해서도 여러 가지 설명이 있으며 조혈 전구세포(hematopoietic precursor cells)의 이상으로 인해 과 립백혈구 전구세포(granulocyte progenitor cells)의 수가 감 소하고 이것이 호중구 생성 감소로 이어지고 있는 것으로 추측
하고 있다 ${ }^{4)}$.

임상적 증상으로는 발열, 실신, 피부감염, 인두염, 임파선염, 두통 등이 있으며 ${ }^{5.6)}$ 보통 호중구의 수가 감소하기 $1 \sim 3$ 일 전 임상적으로 나타나서 약 3 10일 지속 된다 ${ }^{7}$. 구강 내 증상으 로 치은염이 흔하게 발생하며 반복적인 치은염으로 인해 동통 성의 연조직 궤양을 동반한 만성치주염이 나타나고 입술, 혀, 협점막, 치은이 흔하게 이환 된다. 또한, 치조골 파괴를 동반한 급진성 치주조직 상실을 보이기도 한달.

하지만 이러한 임상증상이 나타나는 정도는 사람에 따라 다 르기 때문에 주기성 호중구 감소증이지만 미약한 임상증상으로 환자와 보호자가 모르고 있는 경우가 있으며 적극적인 치료와 예방을 하지 못해 치아와 지지골의 조기상실이 발생하는 경우 가 있다. 따라서 치과의사는 환자를 정기적으로 검진할 때 환자 의 치은질환이 통상적인 치주치료에 의해 개선되지 않거나 다

\section{Corresponding author : Seon-Mi Kim}

Department of Pediatric Dentistry, School of Dentistry, Chonnam National University, 77 Yongbong Street, Buk-Gu, Gwangju, Korea

Tel: +82-62-530-5668 / Fax: +82-62-530-5669 / E-mail: Impedo@jnu.ac.kr

Received December 22, 2012 / Revised May 14, 2013 / Accepted May 14, 2013 
른 특이한 전신질환이 없을 때 주기적 호중구 감소증을 염두에 두고 혈액검사를 받을 수 있도록 해야 한다.

본 증례는 주기성 호중구 감소증으로 약물치료를 받고 있는 만 4세 1 개월 남자아이의 구강 내 소견과 치료에 대해 알아보 고자 한다.

\section{II. 증 례}

만 4세 1 개월의 남아가 잇몸이 많이 붓고 이가 흔들린다는 것 을 주소로 본과에 내원하였다. 환아는 생후 23개월 때 주기성 호중구 감소증으로 진단받았으며 그 후로 현재까지 전남대학교 병원 소아과에서 정기검진 및 혈액검사를 받고 있다. 환아의 호 중구 수는 약 3 주를 주기로 하여 급격히 감소하고 이 기간에 발 열, 치은부종 등의 임상증상이 동반된다고 하였다(Fig. 1).

환아는 고열로 인해 수차례 입원하였으며 약물치료로서 Cephalosporin $\left(\right.$ Ceftezol $^{\circledR}$, Epocelin $\left.^{\circledR}\right)$, Aminoglycoside 계 열의 항생제 $\left(\operatorname{Neticin}^{\circledR}, \mathrm{Isepacin}^{\circledR}\right)$ 와 함께 과립구 집락 자극인 자(granulocyte colony-stimulating factor, G-CSF)를 투여 받았다.

환아는 약 2 년 전 우식 치료를 받은 치과병력이 한번 있으며 그 이후로 잇몸이 붓고 피가 자주 났으나 치료는 받지 않았다고 하였다. 본과 내원 2 주 전 악하 공간과 치은의 부종이 보여 개 인 치과의원에서 치료하였으나 호전양상이 보이지 않아 환아의 소아과 주치의에 의해 본과로 의뢰되어 왔다. 환아의 본과 내원 2 일 전 혈액검사소견은 $\mathrm{WBC} 4700 \mathrm{cells} / \mu \mathrm{L}$ (정상 $5,000 \sim 10,000$ cells $/ \mu \mathrm{L}$ ), $\mathrm{ANC} 60$ cells $/ \mu \mathrm{L}$ (정상
1,000 1,500 cells/ $\mu \mathrm{L}$ ), Hgb $8.5 \mathrm{~g} / \mathrm{dL}$ (정상 $11 \sim 16 \mathrm{~g} / \mathrm{dL}$ ), $\mathrm{PLT} 541 \times 10^{3}$ cells $/ \mu \mathrm{L}$ (정상 $150 \sim 400 \times 10^{3}$ cells $/ \mu \mathrm{L}$ )로서 절대호중구의 수치가 양호하지는 않았으나 환아의 주치의는 시 술 전, 후 항생제 투여와 함께 발치 치료는 가능하다고 판단하 여 5일전부터 Epocelin ${ }^{\circledR}$ (Ceftizoxime sodium, 3회/day, 0.3 $\mathrm{g} /$ 회)를 투여하였고 퇴원 시 Fullgram ${ }^{\circledR}$ (Clindamycin, 3회 /day, $0.5 \mathrm{~g} /$ 회)를 처방하였다.

임상검사 결과, 하악 전치부 5 개(하악 좌 - 우 유중절치, 유측 절치와 하악 좌측 유견치)의 치아를 제외한 나머지 모든 치아에 우식이 있었으며, 하악 좌 · 우 제 1 유구치는 약 2 도의 동요도를 보였다. 치은은 치간유두, 변연치은, 부착치은을 포함하여 전반 적으로 발적, 부종 상태였으며 협점막과 부착치은에서 궤양이 발견되었다(Fig. 2). 전반적으로 치태침착이 심하고 구강위생

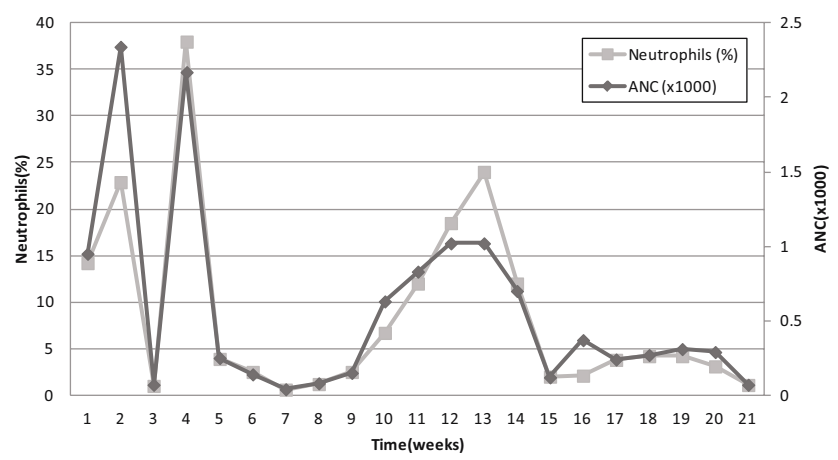

Fig. 1. Absolute neutrophil counts (ANC) and percentage of neutrophils in a patient with cyclic neutropenia showing periodic decrease.
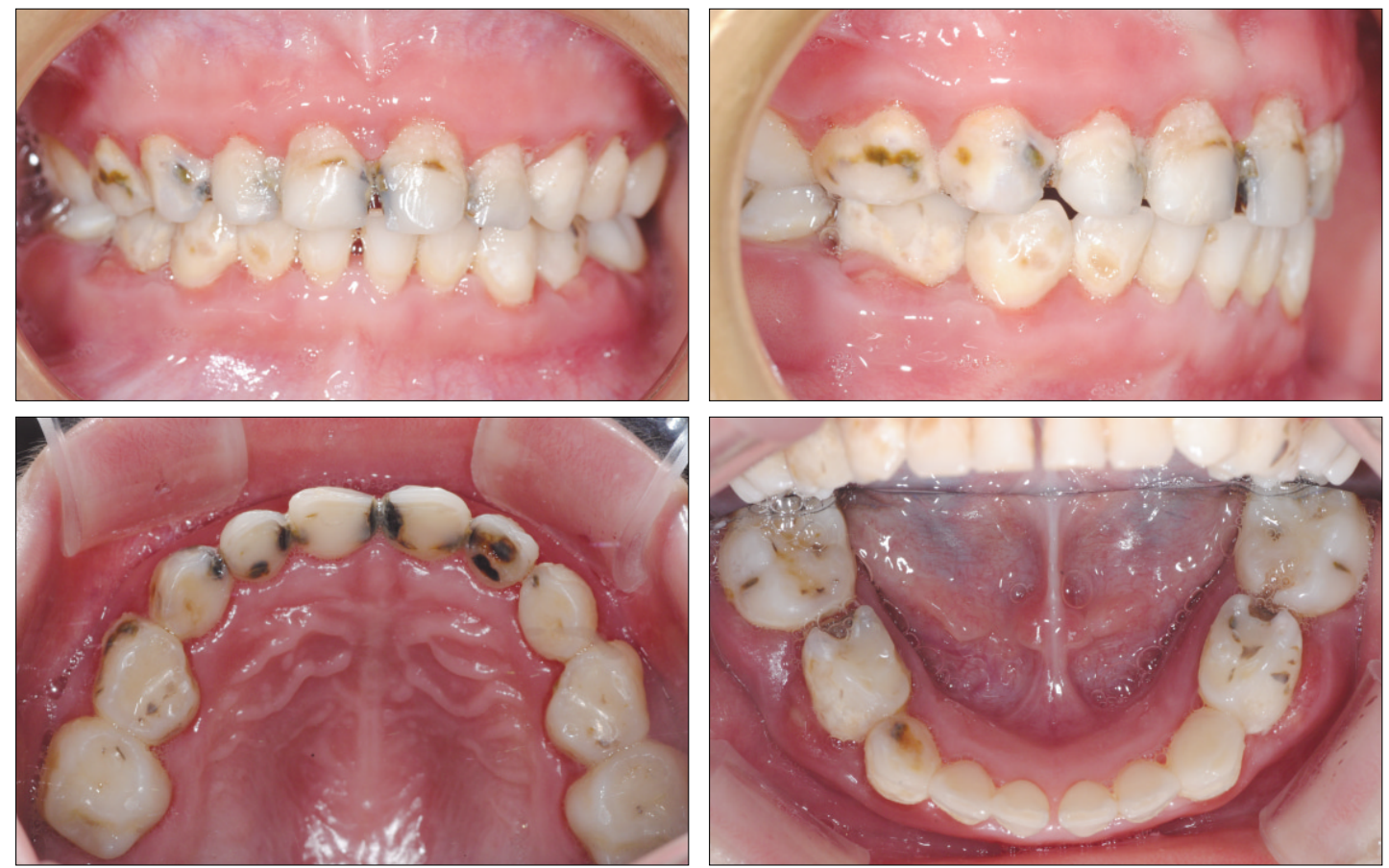

Fig. 2. Intraoral finding of a patient showing gingival inflammation, multiple dental caries and poor oral hygiene at the first visit. 
상태가 매우 좋지 않은 상태였으나 환아는 어떠한 구강질환 예 방처치를 받은 경험이 없었다. 파노라마 방사선사진과 치근단 방사선사진 촬영 결과에서도 다수의 치아우식을 확인할 수 있 었으며, 특히 동요도가 있는 하악 좌 - 우 제 1 유구치 부분의 국 소적 치조골 상실을 확인할 수 있었다(Fig. 3, 4).

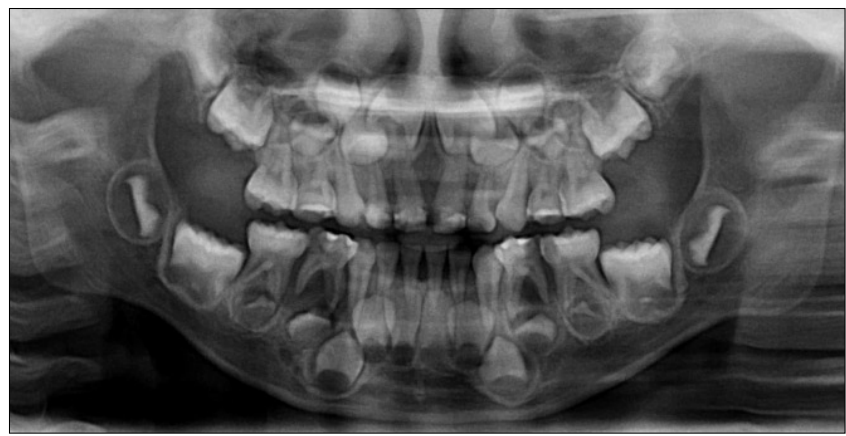

Fig. 3. Initial panoramic radiograph showing the alveolar bone loss of $\# 74,84$.
이에 본 환자를 주기성 호중구 감소증에 기인한 광범위한 치 아우식증, 치은염, 국소적 치주염이라고 진단하고 치료계획을 수립하였다. 환아가 치료를 위한 술 전 항생제를 투여한 상태로 내원하였으나 보호자와 상담 후, 환자의 연령, 협조도 등의 문제 로 진정요법을 동반한 치료를 하기로 하고 다음 약속을 하였다.

환아는 다음날 내원하였으며 치료 1시간 전 술 전 항생제를 투여한 후 진정요법을 사용하여 치료를 시행하였다. 상악 좌측 제 1,2 유구치와 하악 좌측 제 2 유구치는 복합레진수복을 하였으 며 국소적 치조골 상실과 함께 동요도를 보인 하악 좌측 제 1 유 구치는 치수절제술을 시행하였다. 이후 나머지 치료를 위한 내 원 약속을 하였으나 보호자의 요구로 몇 차례 연기되었다.

환아는 약 3 달 후 예방적 항생제를 복용하고 내원하였다. 동 요도가 있었던 하악 좌 - 우 제 1 유구치는 더 증가된 동요도를 보였고 구강위생상태도 여전히 불량하였다. 당일 하악 좌측 제 1 유구치의 치수 치료를 마무리하고 기성금속관으로 수복하였 다. 그리고 동요도를 보인 또 다른 치아인 하악 우측 제 1 유구치 의 치수절제술을 시행하고 당일 마무리하여 역시 기성금속관으 로 수복하였다. 상악 우측 제 1,2 유구치와 하악 우측 제 2 유구치 는 복합레진으로 수복하였다(Fig. 5).
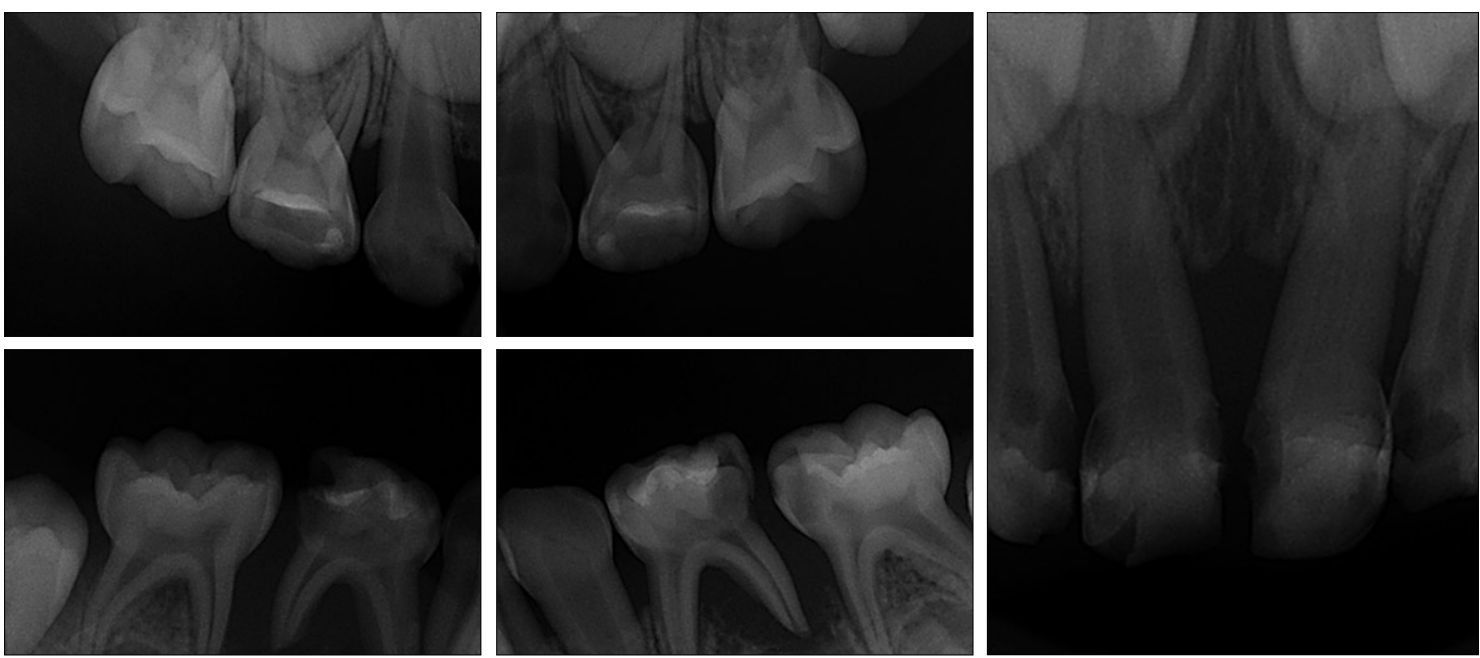

Fig. 4. Initial periapical radiograph showing multiple dental caries.
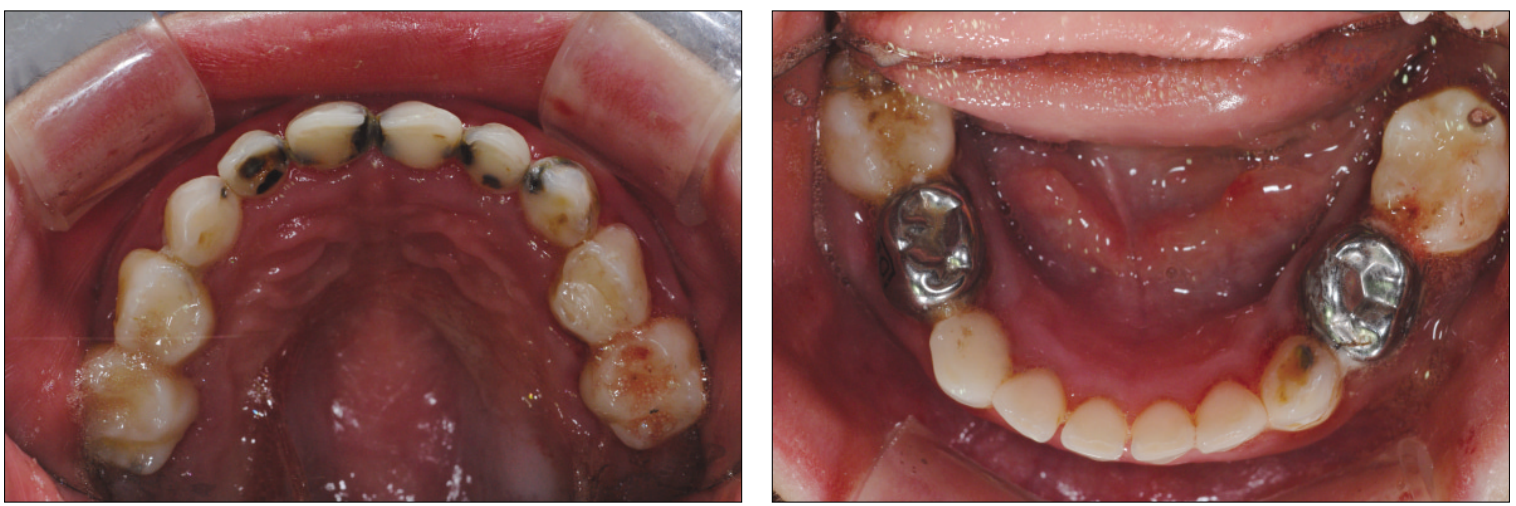

Fig. 5. Intraoral views of a patient showing composite restoration and stainless steel crown restoration on primary molar. 

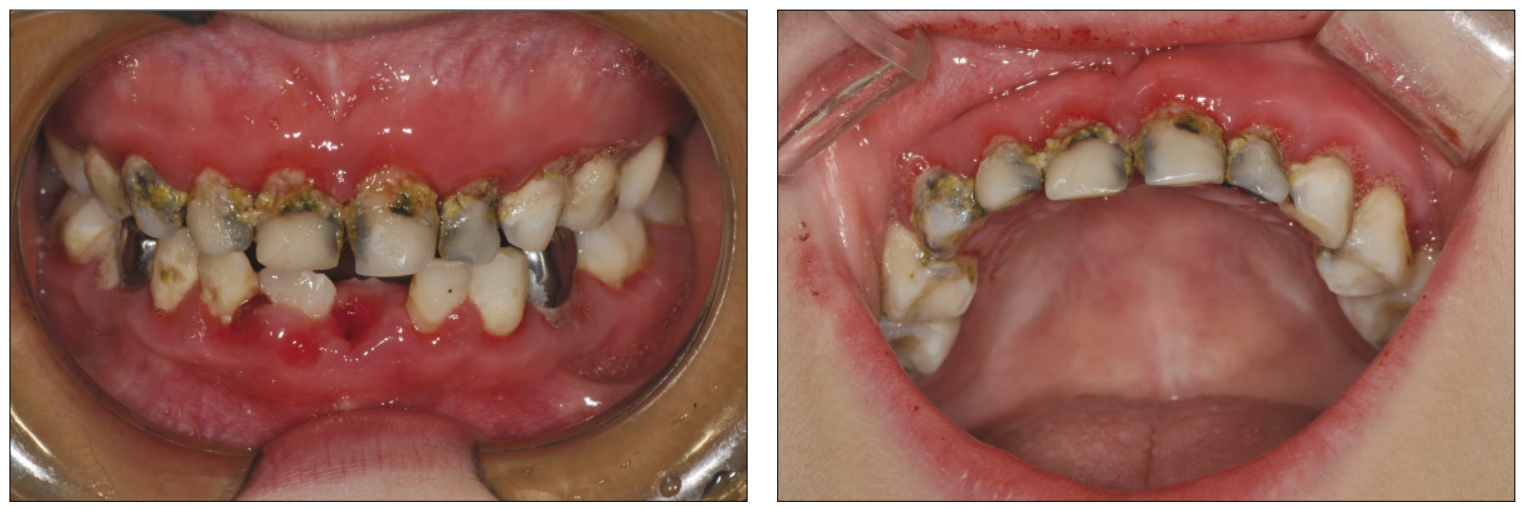

Fig. 6. Intraoral views of a patient showing severe gingivitis and dental plaque deposition on cervical area of upper teeth.

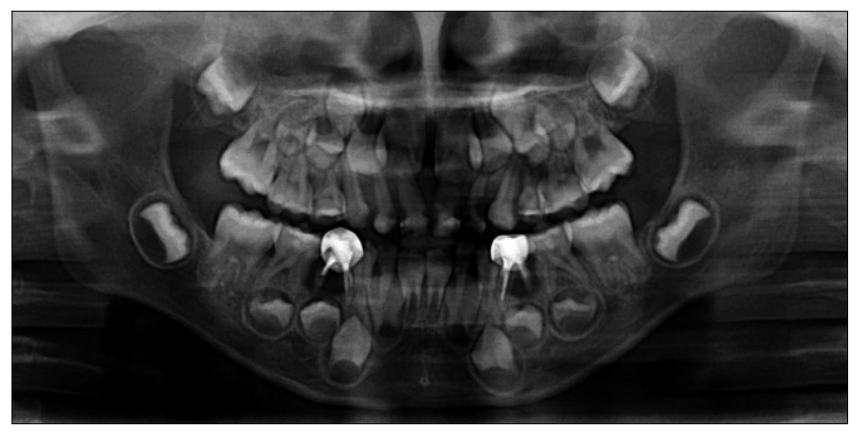

Fig. 7. Panoramic radiograph showing severe alveolar bone loss of \#74, 84 compared with moderated alveolar bone loss of \#74, 84 at first visit.

상악 전치부를 포함한 나머지 우식치에 대한 치료와 치주치 료 및 구강위생관리를 위해 정기적 내원 약속을 하였으나 보호 자의 요구로 몇 차례 연기되었고 약 10 개월 후 하악 유전치가 많이 흔들린다는 것을 주소로 내원하였다. 환아의 상악 유전치 부 치은은 염증이 매우 심했으며 전반적인 구강위생 상태 역시 매우 좋지 않았다(Fig. 6). 또한 초진 시 동요도를 보여 치수절 제술과 기성금속관으로 수복 치료한 하악 좌 - 우 제 1 유구치의 골소실이 더 진행되었음을 방사선 상진에서 확인할 수 있었다 (Fig. 7). 하악 유전치 발거를 위해 예방적 항생제 처치 후 발거 를 시행하고 조심스러운 치태제거와 치면세마 후 당일 불소이 온도포를 시행하였다.

정기적인 구강관리를 위해 내원 약속을 다시 하였고 전문가 에 의한 치태제거와 정기적 불소도포를 계획하였으나 아직까지 재내원 하지 않은 상태이다.

\section{III. 총괄 및 고찰}

본 증례는 주기성 호중구 감소증 환자의 전신질환과 관련된 혈액학적 변화와 이에 따른 구강 내 소견 및 치료내용을 소개하 고 있다. 주기성 호중구 감소증은 어린 나이에 미처 발견하지 못한 채 적절한 치료를 받지 못하는 경우가 다수이다. 감염에
매우 취약한 신체적 조건 탓에 구강에 특징적인 임상증상을 나 타내기 때문에 치과 의료진의 주의 깊은 관찰이 필요하다.

주기성 호중구 감소증은 1910 년 Leale ${ }^{3)}$ 에 의해 최초로 문헌 에 소개되었으며 말초혈액에서 순환성 다형핵 백혈구(circulating polymorphonuclear leukocytes, PMN)수가 감소하면서 중성구의 수치가 $200 \mathrm{cells} / \mu \mathrm{L}$ 이하로 감소하는 것이 특징인 드문 혈액질환이다. 호중구 감소기간인 3 5일 동안 혈중 호중 구 수치는 $0.2 \times 10^{9} \mathrm{cells} / \mu \mathrm{L}$ 이하로 떨어지며 그 후 정상에 가 까운 $2.0 \times 10^{9} \mathrm{cells} / \mu \mathrm{L}$ 로 증가하고 이러한 수치가 다음 호중 구 감소기간까지 유지되는 특징이 있다 ${ }^{9}$. 주기성 호중구 감소증 의 진단을 위해 Dale 등이에 의한 기준이 폭넓게 사용되고 있으 나 임상적 증상과 반응이 매우 다양하여 명확한 진단이 어렵다. Dale 등 ${ }^{10}$ 에 의한 기준은 절대 호중구 수치가 $0.5 \times 10^{9} \mathrm{cells} / \mu \mathrm{L}$ 이하로 감소되는 기간이 3 5일간 유지되어야 하며 이러한 주 기를 6 개월 내에 세 번 이상 겪어야 한다는 것이다.

중성구는 세균감염에 대한 신체의 첫 번째 방어기제로 작용 하기 때문에 이러한 중성구의 감소는 신체를 감염에 매우 취약 하게 만들어 호중구 감소 동안 여러 임상증상을 보이게 된다. 전신적 증상으로는 고열, 두통, 만성기침, 피부감염, 중이염, 전 신적인 피로감이 있으며 구강 내 증상으로는 치은 염증, 치은 퇴축, 치아 동요, 다발성 우식, 구강 연조직 궤양 등이 있다. 특 히 반복적인 치은염과 치주질환은 어린 나이의 환자에게서도 주기적이고 만성적인 치조골 소실을 일으킬 수 있으며 이로 인 한 조기 치아 상실을 유발하기도 한다. 본 증례의 환아는 호중 구 감소기간동안 고열로 인한 응급 입원이 많았으며 좋지 않은 구강위생으로 인한 다발성 우식과 국소적 치조골 상실이 동반 되었고 호중구 감소증 환자에서 특징적인 구강 내 궤양은 심하 지 않았다.

주기성 호중구 감소증의 치료방법은 구강병소에 대한 전신적 혹은 국소적 항생제 처치, 코르티코스테로이드 처치, 과립구 집 락 자극인자 $(\mathrm{G}-\mathrm{CSF})$ 의 투여, 골수이식 등이 알려져 있다. 특 히 G-CSF는 1980년대 후반과 1990년대 초반에 수많은 임상 시험을 기반으로 하여 현재 여러 나라에서 승인되었고 계속해 
서 임상사용 가이드라인이 개정되고 있는 방법이다(Table 1). $\mathrm{G}-\mathrm{CSF}$ 는 스트레스에 반응하여 호중구 수치를 증가시키고 정 상수준으로 유지하는데 필수적인 당단백질 성분의 사이토카인 이다. 이는 호중구의 기능적 성숙과 분화를 유도하며 다른 사이 토카인과 함께 주화성, 식세포작용, 항체 의존성 세포 매개 세 포독성을 향상시킨다. 합성된 $\mathrm{G}-\mathrm{CSF}$ 는 호중구 감소증을 치료 하거나 증상호전을 위해 임상에 사용되는 유일한 생물학적 반 응 조절자로서 최근에는 armamentarium을 첨가하여 반응 기 간을 연장한 $\mathrm{G}-\mathrm{CSF}$ 를 호중구 감소증에 사용하고 있다 ${ }^{11}$.

US FDA에서 추천하고 있는 G-CSF의 용량은 $5 \mu \mathrm{g} / \mathrm{kg} / \mathrm{day}$ 이다. 피하주사가 선호되지만 정맥투여도 가능하며 절대 호중 구수가 $2 \sim 3 \times 10^{9}$ cells $/ \mu \mathrm{L}$ 수준이 되면 투여를 중지 한다 ${ }^{12)}$. 하지만 $\mathrm{G}-\mathrm{CSF}$ 치료의 시작 시 경미한 골의 통증과 두통이 있 을 수 있으며 이 때문에 임상적으로는 적은 용량 $(1 \mu \mathrm{g} / \mathrm{kg} / \mathrm{day})$ 으로 시작하여 필요시 점점 용량을 증가시키는 것이 좋다고 한 다 ${ }^{13)}$.

본 증례의 환아도 여러 차례에 걸쳐 과립구 집락 자극인자를 투여 받았다. 환아는 과립구 집락 자극인자의 투여에도 호중구 수의 급격한 감소가 주기적으로 반복되었으나 이 기간에 발열, 치은염 등 임상증상의 발현 정도와 그 빈도가 감소하여 과립구 집락 자극인자의 긍정적인 효과를 확인할 수 있었다. Sergio 등 14 의 증례에서도 한 달에 한 번 $\mathrm{G}-\mathrm{CSF}$ 의 투약을 실시하여 호중 구 감소기간 동안 구강궤양 등의 임상증상이 사라지는 것을 확 인하였다.

주기성 호중구 감소증 환자의 구강증상 및 치료를 소개한 이 전의 여러 증례에서 동일하게 강조하고 있는 것은 우식치의 수 복치료뿐 아니라 치주치료의 중요성이다 ${ }^{1.24 .5)}$. 1984년 Prichard 등흔 즌 주기성 호중구 감소증 환자에 있어서 $\mathrm{CBC}$ (complete blood cell count)가 높은 상태일 때마다 환자를 정 기적으로 내원시켜 전문가에 의한 적극적인 구강관리 즉 전문 가에 의한 치면 세마와 정기적 치석 제거술을 시행하는 것이 환 자의 치주조직을 건강하게 유지하고 치조골과 치아상실을 가능 한 한 연기시켜줄 수 있다고 주장하였다. 본 증례의 환아는 과 거 충치치료의 경험은 있으나 치주조직에 대한 치료나 예방적 치료는 단 한 번도 받지 않았다고 하였으며 치은염 뿐 아니라 국소적인 치조골 상실을 동반한 치주질환이 확인되어 정기적인 치주 관리와 위생관리를 계획하였다. 환자는 3 주를 주기로 호 중구의 수가 감소하였으므로 호중구의 수가 정상범주일 때 내 원하도록 계획을 잡고 전문가에 의한 치면 세마, 치은 연하 치 태관리, 정기적 불소도포 등을 시행하기로 하였으나 보호자에 의해 내원약속이 지켜지지 않아 정기적 관리는 시행하지 못하 였다.

주기성 호중구 감소증 환자의 치주치료의 목표는 치은염증의 감소에 있으며 치조골 소실을 늦추는데 있다. 하지만 술 후 감 염의 높은 위험성 때문에 적극적인 치료는 호중구수가 회복될 때까지 기다려야 하며 응급의 경우 적절한 예방적 항생제 처치 후 시행되어야한다 ${ }^{15)}$. 본 증례의 환아 역시 본과에 초진 내원 시 소아과 주치의에 의해 5 일간 항생제 치료(Cephalosporin,
Clindamycin)를 받은 상태였다. 항생제는 예방과 치료를 목적 으로 치과에서 사용 가능하며 예방적 항생제는 특히 심내막염 을 막기 위해 그리고 치료적 항생제는 구강의 연조직 질환의 치 료를 위해 국소적 또는 전신적으로 사용하는 경우가 많다. 예방 적 항생제 처치의 궁극적인 목표는 감염예방이다. 따라서 감염 의 위험성이 큰 환자가 적응증이 되며 이는 치료의 범위와 환자 의 전신 상태에 따라 결정된다. 미국소아치과학회(American Academy of Pediatric Dentistry, AAPD)는 미국심장협회 (American Heart Association's, AHA)의 감염성 심내막염을 막기 위한 예방적 항생제 가이드라인을 따르고 있으며(Table $2,3)$ 이 외에도 손상된 면역체계를 가지고 있는 환자 예를 들 어, HIV 환자, 중증 복합형 면역 부전증 환자, 백혈구 감소증 환자, 만성 스테로이드 사용 환자, 당뇨 등의 환자는 침습적인 치과치료 후 전이성 균혈증이 발생할 가능성이 크기 때문에 예 방적 항생제 처치가 반드시 필요하다 ${ }^{16.17)}$. 주기성 호중구 감소 증 환자는 일차적인 면역 기능을 담당하는 호중구의 수가 부족 하기 때문에 감염에 특히 민감하며 이와 관련하여 보호자의 우 려가 크기 때문에 적절한 예방적 항생제의 술 전 투약이 반드시 시행되어야 한다.

예방적 목적이 아닌 호중구 감소증 환자의 치료를 위한 항생 제 처치는 2003년 Yukie Nakai 등')의 증례에서 소개된 것과 같이 정기적 내원 하에 조심스러운 치은연하 치태제거술을 시 행하고 국소적 혹은 전신적으로 항생제를 처치 할 수 있다. 이 러한 항생제 치료가 치주조직의 급격한 손실을 막아준다고 하 였으며 특히, 전신적 항생제보다 국소적 항생제 처치가 항생제 저항성 세균(antibiotic-resistant bacteria)생성이 적고 치주 낭 부분에 고농도의 항생제가 직접 전달된다는 점에서 더 효율 적이라고 하였다. 하지만 Dalaney와 Keels ${ }^{18}$ 의 주장대로 치주 질환의 치료를 위해서는 항생제 처치가 아니라 국소적 자극원 을 제거하는 것이 더 중요하다는 것을 알아야 한다.

본 증례 환자의 경우 치과 치료를 위한 본과 내원뿐 아니라 주기성 호중구 감소증 치료를 위한 소아과 내원도 정기적으로 이뤄지지 않는 모습을 보였다. 앞서 언급한 데로 감염에 의한 구강조직의 조기 상실을 막기 위해서는 전문가에 의한 정기적 인 관리가 필수이다. 하지만 본 증례와 같이 보호자에 의해 정 기적 내원이 이뤄지지 않는 경우도 있다. 따라서 치과 의료진은 이러한 경우까지 충분히 고려하여 환자의 치료계획 중 일부로 보호자 교육을 포함해야 할 것이다. 호중구의 수가 감소하는 시 기의 환자 구강은 궤양이 자주 생겨 환자는 음식을 먹는 것, 칫 솔질하는 것 등에 의해 통증을 호소하게 된다. 본 증례의 보호 자처럼 구강위생교육을 받지 않은 대부분의 보호자는 칫솔질로 환자가 통증을 호소할 때면 칫솔질을 불충분하게 하거나 포기 해 버리는 경우가 많다. 하지만 주기성 호중구 감소증에는 통증 을 호소하는 동안에도 적절한 구강위생관리가 필수이기 때문에 보호자는 올바른 칫솔질과 치실 사용법뿐 아니라 통증을 고려한 구강위생관리에 대해서도 교육을 받아야 한다. Prichard 드이은 주기성 호중구 감소증 환자의 궤양으로 인한 구강 내 통증을 경 감시키기 위해 $2 \%$ viscous lidocaine hydrochloride 또는 dy- 
clonine hydrochloride $(0.5 \%$ 또는 $1.0 \%)$ 도포마취제를 사용 하였다. 하지만 이런 마취성분은 구강 내 궤양이 있거나 개방성 창상이 있을 경우 흡수가 빨라 부적절하게 사용하게 되면 심혈 관계 또는 중추신경계에 영향을 끼칠 수도 있다. 따라서 가정에 서 사용하기 위해서는 보호자가 충분한 교육을 받아야 한다. 통 증이 있을 경우 이러한 도포마취제 사용과 더불어 chlorohexidine을 이용한 구강세척이 구강위생관리를 더 효과적으로 해줄 수 있다 ${ }^{11}$.

주기성 호중구 감소증 환자에서 치아우식이 더 많이 발생하 는지에 대한 명확한 결론은 아직 없다. 수개월 뒤 내원한 본 증 례의 환아도 여전히 구강위생관리가 좋지 않고 전반적인 치태 침착이 있었으나 다행히도 추가적인 치아우식이 발견되지 않았 고 기존의 우식상태가 더 심해지지도 않았다. 주기성 호중구 감 소증 환자의 충치감염 위험도는 낮은 수준이라고 판단할 수 있 으며 이 수준을 유지하는 것이 또한 중요하다 할 수 있다. 이는 수복치료 방법을 결정할 때 고려해야 할 조건으로서, 수복치료 후 환자의 구강관리 측면을 고려하였을 때 이차적인 우식이나 치주병소를 유발하지 않는 치료방법을 선택해야 한다. 이런 점 에서 주기성 호중구 감소증 환자의 인접면 우식 치료(2급 와동) 는 국소적 치주염을 유발할 수 있기 때문에 피해야 한다 ${ }^{1)}$. 본 증례에서 치조골 상실과 함께 치근단 농양 소견을 보인 하악 좌 - 우 제 1 유구치는 치수절제술에 이어 기성금속관으로 수복하 였는데 이차우식과 국소적 치주염의 발생을 최대한 막기 위해 금속관과 치아의 치경부 적합성이 최대가 되도록 주의하여 시 술하였다.

주기성 호중구 감소증 환자의 치과적 임상증상과 장기간 치 료에 관한 연구나 증례는 아직 그리 많지 않다. 주기성 호중구 감소증 환자는 평생 구강관리가 필요하며 특히 유치열의 환자 일 경우 영구치열기가 완성될 때까지 조기 치조골 상실, 조기 치아 상실로 인한 영구치 맹출 공간 부족 등을 최소화하는 것이 중요하다. 이를 위해 어린 나이의 주기성 호중구 감소증 환자에 있어서 장기간의 추적조사를 바탕으로 하여, 정기적 구강위생 관리와 적극적인 치료 및 예방으로 조기 치조골 상실, 조기 치 아상실, 급격한 치주조직 파괴 등 구강조직의 손실을 최대한 줄 일 수 있는 방법이 소개되고 더 연구되어야 할 필요성이 있다.

\section{IV. 요 약}

본 증례는 주기성 호중구 감소증으로 약물치료를 받고 있는 만 4세 1 개월 남자아이의 구강 내 소견과 치료를 소개하고 있 다. 주기적인 면역학적 방어기제의 감소 때문에 구강이 감염에 취약해지고 염증, 궤양 등에 의한 통증에 의해 가정에서의 구강 위생관리도 어렵게 된다. 결국, 전문가에 의한 정기적인 구강위 생관리와 함께 치아우식, 치은염에 대한 시기적절한 치료가 필 요하다고 볼 수 있으며 특히 어린 환자들에 있어서 영구치열기 형성에 장애가 발생하지 않도록 조기에 적극적인 개입을 하는 것이 중요하다.

\section{References}

1. Souid AK : Congenital cyclic neutropenia. Clin Pediatr, 34:151-5, 1995.

2. Marcio A. Fernanda F : Early tooth loss due to cyclic neutropenia: long-term follow-up of one patient. SCD, 20:187-190, 2000.

3. Leale $M$ : Recurrent furunculosis in an infant show ${ }^{-}$ ing an unusual blood picture. JAMA, 54:1854-1855, 1910.

4. Nakai Y, Ishihara C, Ogata S, Shimono T : Oral manifestations of cyclic nertropenia in a Japanese child: case report with a 5-year follow-up. Pediatr Dent, 25:383-388, 2003.

5. Pernu HE, Pajari UH, Lanning M : The importance of regular dental treatment in patients with cyclic neutropenia. Follow-up of 2 cases. J Periodontol, 67:454-459, 1996.

6. Prichard JF, Ferguson DM, Windmiller J. Hurt WC : Prepubertal periodontitis affecting the deciduous and permanent dentition in a patient with cyclic neutropenia. J Periodontol, 55:114-122, 1984.

7. Spencer P, Fleming JE : Cyclic neutropenia: a literature review and report of case. J Dent Child, 52:108-113, 1985.

8. Binon PP, Dykema RW : Rehabilitative management of cyclic neutropenia. J Prosthet Dent, 31:5260, 1974.

9. Guerry D, Dale DC, Omine M, et al. : Periodic hematopoiesis in human cyclic neutropenia. J Clin Invest, 52:3220-3230, 1973.

10. Dale DC, Bonilla MA, Lalezari P, et al. : A randomized controlled phase III trial of recombinant human granulocyte colony stimulating factor (filgrastim) for treatment of severe chronic neutropenia. Blood, 81:2496-2502, 1993.

11. Rami SK, Gary HL : The colony-stimulating factors: use to prevent and treat neutropenia and its complications. Expert Opin Biol Ther, 4:1897-1910, 2004.

12. Ozer H, Armitage JO, Bennett CL, et al. : 2000 update of recommendations for the use of hematopoietic colony-stimulating factors: evidencebased, clinical practice guidelines. J Clin Oncol, 18:3558-3585, 2000.

13. David CD, Audrey AB, Andrew A : Cyclic Neutropenia. Semin Hematol, 39:89-94, 2002.

14. Matarasso S, Daniele V, Caflero C, et al. : The Effect of Recombinant Granulocyte-Stimulating 
Factor on Oral and Periodontal Manifestation in a Patient with Cyclic Neutropenia: A Case Report. Int J Dent, 654239, 2009.

15. Mishkin DJ, Akers JO, Darby JP : Congenital neutropenia. Report of a case and a biorationale for dental management. Oral Surg Oral Med Oral Pathol, 42:738-745, 1976

16. American Academy of Pediatric Dentistry(AAPD). Guideline on use of antibiotic therapy for patients at risk of infection: American Academy of Pediatric
Dentistry(AAPD), 2007.

17. American Academy of Pediatric Dentistry. Clinical guideline on dental management of pediatric patients receiving chemotherpy, hematopoietic cell transplantation, and/or radiation. Pediatr Dent, 27:170-175, 2005.

18. Dalaney JE, Keels MA : Pediatric oral pathology. Soft tissue and periodontal conditions. Pediatr Clin North Am, 47:1125-1147, 2000. 


\title{
국문초록
}

\section{주기성 호중구 감소증 환자의 구강 내 소견과 치료에 대한 증례 보고}

\author{
강은주 · 최남기 · 김선미
}

전남대학교 치의학전문대학원 소아치과학교실

주기성 호중구 감소증은 호중구의 수가 감소하였다가 다시 정상으로 회복되는 반응이 주기적으로 나타나는 혈액질환이다. 임상적 증상으로 발열, 실신, 두통 등이 있으며 구강 내 증상으로 동통성 연조직 궤양이 특징적인데 특히 입술, 혀, 협점막, 치은이 흔하게 이환 된다. 또한, 치조골 파괴를 동반한 급진성 치주조직 상실을 보이기도 한다.

본 증례의 환아는 4 세 1 개월의 남아로서 잇몸이 붓고 이가 흔들린다는 것을 주소로 본과에 내원하였다. 환아는 주기성 호 중구 감소증 환자로서 하악 전치부 5 개 치아를 제외한 모든 유치에 우식이 있었으며 동요를 보이는 하악 좌 · 우 제 1 유구치의 국소적 치조골 소실을 확인할 수 있었다. 환아는 주기성 호중구 감소증에 기인한 광범위한 치아우식증, 치은염, 국소적 치주 염으로 진단되었고 치료를 시행하였다.

주기성 호중구 감소증 환자에게는 정기적인 구강위생관리와 함께 치아우식, 치은염에 대한 시기적절한 치료가 필요하며 특 히 어린 환자들에 있어서 영구치열 형성에 장애가 발생하지 않도록 조기에 개입을 하는 것이 중요하다.

주요어: 주기성 호중구 감소증, 치은염, 치조골소실, 구강관리 